\title{
Anti-cyclic citrullinated peptide antibodies and rheumatoid factor in leprosy patients with articular involvement
}

\author{
S.L.E. Ribeiro ${ }^{1,2}$, H.L.A. Pereira ${ }^{1,2}$, N.P. Silva ${ }^{1}$, R.M.S. Neves ${ }^{1}$ and E.I. Sato ${ }^{1}$ \\ 1Disciplina de Reumatologia, Universidade Federal de São Paulo, São Paulo, SP, Brasil \\ 2Disciplina de Reumatologia, Universidade Federal do Amazonas, Manaus, AM, Brasil \\ Correspondence to: E.I. Sato, Disciplina de Reumatologia, UNIFESP, Rua Botucatu, 740, 04023-900 \\ São Paulo, SP, Brasil \\ Fax: +55-11-5579-6665/5576-4239. E-mail: eisato@unifesp.br
}

\begin{abstract}
The objective of the present research was to evaluate the usefulness of anti-cyclic citrullinated peptide (anti-CCP) antibodies and the IgM rheumatoid factor (IgM RF) test for the differential diagnosis of leprosy with articular involvement and rheumatoid arthritis (RA). Anti-CCP antibodies and IgM RF were measured in the sera of 158 leprosy patients (76 with and 82 without articular involvement), 69 RA patients and 89 healthy controls. Leprosy diagnosis was performed according to Ridley and Jopling classification criteria and clinical and demographic characteristics of leprosy patients were collected by a standard questionnaire. Leprosy patients with any concomitant rheumatic disease were excluded. Serum samples were obtained from all participants and frozen at $-20^{\circ} \mathrm{C}$. Measurement of anti-CCP antibodies and IgM RF were performed by ELISA, using a commercial second-generation kit, and the latex agglutination test, respectively. Anti-CCP antibodies and IgM RF were detected in low frequencies (2.6 and 1.3\%, respectively) in leprosy patients and were not associated with articular involvement. Among healthy individuals both anti-CCP antibodies and IgM RF were each detected in $3.4 \%$ of the subjects. In contrast, in the RA group, anti-CCP antibodies were present in $81.2 \%$ and IgM RF in $62.3 \%$. In the present study, both anti-CCP antibodies and IgM RF showed good positive predictive value for RA, helping to discriminate between RA and leprosy patients with articular involvement. However, anti-CCP antibodies were more specific for RA diagnosis in the population under study.
\end{abstract}

Key words: Leprosy; Rheumatoid arthritis; Anti-cyclic citrullinated peptide antibodies; Rheumatoid factor

Publication supported by FAPESP.

Received April 22, 2008. Accepted November 7, 2008

\section{Introduction}

Leprosy is a chronic granulomatous disease caused by Mycobacterium leprae, an obligate intracellular parasite that affects mainly skin and peripheral nerves (1). Although the number of new cases of leprosy is decreasing, the disease still constitutes a major public health problem in many developing countries (2).

The clinical spectrum of leprosy is characterized by two stable polar forms of disease. At one pole, tuberculoid leprosy, the host is able to keep the disease under control due to an efficient T-cell-mediated immune response; while at the opposite pole, lepromatous leprosy, cell-mediated immunity is inefficient leading to excessive bacillary multiplication and dissemination (3). Between the two stable poles are unstable forms of leprosy, named borderline (or dimorphous) that may combine characteristics of the polar forms. Acute inflammatory events, known as reactional episodes, may occur during the chronic course of leprosy, due to either alterations in cellular immunity (type 1 or reversal reaction) or excessive formation of immune complexes at the sites of antigen deposition (type 2 or erythema nodosum leprosum) (4).

Leprosy patients can present a great variability of signs 
and symptoms including arthralgia and arthritis similar to that seen in rheumatic diseases, especially in rheumatoid arthritis (RA) (5-7). The articular involvement in leprosy is considered to be the third most frequent manifestation, after dermatological and neurological involvement. Articular manifestations are reported in frequencies ranging from 1 to $78 \%(8,9)$.

Rheumatoid factor (RF) is reported as positive in 70$80 \%$ of RA patients; however, its specificity is limited since $\mathrm{RF}$ is also detected in sera from healthy elderly individuals and patients with various other autoimmune and infectious diseases, including leprosy (10-13). Although RF presents limited specificity, it is widely used as a diagnostic marker for RA. In contrast, anti-cyclic citrullinated peptide (antiCCP) antibodies display a high specificity (98-100\%) for RA $(14,15)$, associated with a reasonable sensitivity (6774\%) $(16,17)$.

Anti-CCP antibodies have been evaluated in a large number of patients with different autoimmune (16,18-21) and infectious diseases (16,21-24). More recently, a high frequency $(32 \%)$ of anti-CCP antibodies was reported in patients with active lung tuberculosis (24) and another study showed a low frequency of anti-CCP among patients with leprosy, a disease caused by another mycobacterium (25).

The purpose of the present study was to evaluate the usefulness of anti-CCP antibodies and IgM RF in distinguishing patients with leprosy-related articular involvement from those with RA.

\section{Patients and Methods}

The leprosy group was constituted by 158 patients seen at the Tropical Dermatology and Venereal Clinic of Alfredo da Matta Foundation (Manaus, Brazil) from July 2004 to October 2006. Seventy-six patients with articular involvement, characterized by the presence of either arthralgia (pain) or arthritis (pain and joint swelling), and 82 gender- and age-matched patients without articular involvement were studied. Leprosy diagnosis was performed according to Ridley and Jopling classification criteria (3). Careful physical exams and histories as well as medical chart review and rheumatological examinations were performed for all patients by two rheumatologists (S.L.E.R. and H.L.A.P.), and leprosy patients with any concomitant rheumatic disease were excluded.

The RA group comprised 69 patients fulfilling the American College of Rheumatology revised criteria for RA classification (26). The control group was composed by 89 healthy gender- and age-matched individuals to the leprosy group, living in the same city.
The study was approved by both Institutional Review Boards and all participants signed informed consent forms and provided blood samples for laboratory tests. All serum samples were stored at $-20^{\circ} \mathrm{C}$.

\section{Detection of anti-CCP antibodies}

Anti-CCP antibodies were detected by a second-generation ELISA using a commercial kit (Immunoscan RA Anti-CCP test kit; EuroDiagnostica, Sweden), according to manufacturer instructions. In brief, serum samples diluted 1:50 in sample diluent were distributed in microtiter plates and incubated for $60 \mathrm{~min}$ at room temperature. After washing, the plates were incubated for $30 \mathrm{~min}$ at room temperature with the ready-to-use peroxidase conjugated antihuman IgG antibody provided by the kit. After washing, the reaction was developed for $30 \mathrm{~min}$ at room temperature with TMB solution, stopped with phosphoric acid and read at $450 \mathrm{~nm}$ in a plate reader (Multiscan MS, Labsystems, Finland). Pre-diluted anti-CCP standards as well as positive and negative controls were included in each plate. A 4parameter curve fit was used to calculate anti-CCP antibody levels in serum samples. Anti-CCP antibodies were considered to be positive when above the cut-off level of the kit ( $\geq 25 \mathrm{U} / \mathrm{mL})$. The anti-CCP test used shows $75.1 \%$ sensitivity for RA diagnosis, according to the manufacturer.

\section{Rheumatoid factor}

IgM RF was detected by the semi-quantitative latex agglutination test with a commercial kit (RapiTex RF, Germany). According to the manufacturer, IgM RF was considered to be positive when the serum titer was $\geq 1 / 4$ (80 IU/ $\mathrm{mL})$.

\section{Statistical analysis}

The Mann-Whitney and Kruskal-Wallis tests were used for comparing age distribution among groups. The chisquare test was used to compare the gender distribution, and anti-CCP antibodies and RF frequencies between groups. $P$ values $<0.05$ were considered to be statistically significant. Statistical analysis was performed with the SSPS-10 software.

\section{Results}

Among leprosy patients, $113(71.5 \%)$ were male and $45(28.5 \%)$ were female $(P=0.001)$. Among 76 patients with articular involvement, 61 (80.3\%) presented polyarthritis and 15 (19.7\%) presented polyarthralgia. According to the clinical classification, lepromatous leprae was the most frequent form of leprosy, found in $38.2 \%$ of the 
patients with articular involvement and in $32.9 \%$ of the patients without articular involvement. Regarding specific treatment, $40.5 \%$ of leprosy patients were receiving polychemotherapy and $59.5 \%$ had finished polychemotherapy. Reactional episodes were present in $36.7 \%$ of the leprosy patients (Table 1 ).

No differences were found between leprosy patients with and without articular involvement in terms of gender, age, clinical classification, use of specific medication or occurrence of reactional episodes (Table 1).

The RA group was composed of 62 women and 7 men (mean age of $45.3 \pm 13.0$ years and mean disease duration of $115.77 \pm 99.44$ months). The gender and age distributions of the RA group differed from the leprosy and control groups.

The healthy control group was composed of 66 males and 23 females, with mean age of $41.6 \pm 14.63$ years (range, 19 to 77 years). The age and gender distributions of this group were similar to the leprosy group.

Anti-CCP antibodies were detected in $56(81.2 \%)$ of the 69 RA patients and in only $4(2.5 \%)$ of the 158 leprosy patients, none of them with articular involvement. IgM RF was detected in $62.3 \%$ of RA patients and in only 2 (1.3\%) leprosy patients, both with polyarthritis (Table 2). No significant difference was found between leprosy patients with and without articular involvement regarding the frequency of anti-CCP antibodies and IgM RF.

Among healthy controls, 3 individuals (3.4\%) were anti-CCP positive; 2 of them with low to moderate titers (44 and $53 \mathrm{U} /$ $\mathrm{mL}$ ) and the third one with a high titer (1827 U/mL). Regarding IgM RF, we also found 3 positive individuals, 2 with low titers of $\operatorname{lgM}$ RF $(80 \mathrm{IU} / \mathrm{mL})$ and 1 with a high titer of IgM RF (1280 IU/mL). Only 1 control presented high titers of anti-CCP and IgM RF.

Figure 1 shows the distribution of antiCCP titers among patients with leprosy (with and without articular involvement), healthy controls and RA patients (IgM RFpositive and -negative).

Regarding RA diagnosis, the specificity of anti-CCP was similar to IgM RF (97.2 and $98 \%$, respectively). However, the sensitivity of anti-CCP was significantly higher than $\lg M$ RF (81.2 and $62.3 \%$, respectively, $P=0.012$ )

\section{Discussion}

In the present study, both anti-CCP antibodies and IgM RF proved to be equally useful and specific to distinguish between leprosy with articular involvement and RA. However, anti-CCP was found to be more sensitive than IgM RF.

The anti-CCP positivity found among RA patients in the present study is in agreement with Dubucquoi et al. (27), who reported a sensitivity of $85 \%$. The anti-CCP2 test used in our study has higher sensitivity than the anti-CCP1 test (28).

Table 1. Demographic characteristics, specific treatment and reactional episodes of 158 leprosy patients with and without articular involvement (Al).

\begin{tabular}{|c|c|c|}
\hline $\begin{array}{l}\text { Characteristics of } \\
\text { patients }(N=158)\end{array}$ & $\begin{array}{c}\text { Leprosy with } \mathrm{Al} \\
(\mathrm{N}=76,48 \%)\end{array}$ & $\begin{array}{l}\text { Leprosy without Al } \\
\quad(\mathrm{N}=82,52 \%)\end{array}$ \\
\hline Age (mean $\pm S D$ in years) & $39.88 \pm 15.77$ & $39.77 \pm 14.80$ \\
\hline \multicolumn{3}{|l|}{ Gender } \\
\hline Male & $51(67 \%)$ & $62(76 \%)$ \\
\hline Female & $25(33 \%)$ & $20(24 \%)$ \\
\hline Polyarthritis & $61(80 \%)$ & $0(0 \%)$ \\
\hline Polyarthralgia & $15(20 \%)$ & $0(0 \%)$ \\
\hline \multicolumn{3}{|l|}{ Clinical classification } \\
\hline Indeterminate leprosy & $2(3 \%)$ & $2(2 \%)$ \\
\hline Tuberculoid & $2(3 \%)$ & $4(5 \%)$ \\
\hline Tuberculoid borderline & $16(21 \%)$ & $16(20 \%)$ \\
\hline Borderline borderline & 12 (16\%) & $13(16 \%)$ \\
\hline Lepromatous borderline & $15(20 \%)$ & $20(24 \%)$ \\
\hline Lepromatous & $29(38 \%)$ & $27(33 \%)$ \\
\hline \multicolumn{3}{|l|}{ Current specific treatment } \\
\hline None (treated) & $50(66 \%)$ & $44(54 \%)$ \\
\hline Polychemotherapy & $26(34 \%)$ & $38(46 \%)$ \\
\hline \multicolumn{3}{|l|}{ Reactional episodes } \\
\hline Present & $24(32 \%)$ & $34(42 \%)$ \\
\hline Absent & $52(68 \%)$ & $48(59 \%)$ \\
\hline
\end{tabular}

Data are reported as number of patients with percent in parentheses.

Table 2. Prevalence of anti-CCP antibodies and IgM RF in the serum of leprosy and rheumatoid arthritis patients and healthy controls.

\begin{tabular}{lcccc}
\hline Variable & $\begin{array}{c}\text { Leprosy with } \\
\mathrm{Al}(\mathrm{N}=76)\end{array}$ & $\begin{array}{c}\text { Leprosy without } \\
\mathrm{Al}(\mathrm{N}=82)\end{array}$ & $\begin{array}{c}\text { Rheumatoid arthritis } \\
(\mathrm{N}=69)\end{array}$ & $\begin{array}{c}\text { Controls } \\
(\mathrm{N}=89)\end{array}$ \\
\hline Anti-CCP & $0(0 \%)$ & $4(5 \%)$ & $56(81 \%)$ & $3(3 \%)$ \\
IgM RF & $2(3 \%)^{*}$ & $0(0 \%)$ & $43(62 \%)$ & $3(3 \%)$ \\
\hline
\end{tabular}

Data are reported as number of patients with percent in parentheses. $\mathrm{Al}=$ articular involvement; Anti-CCP = anti-cyclic citrullinated peptide antibodies; RF = rheumatoid factor. *Both patients had polyarthritis. 


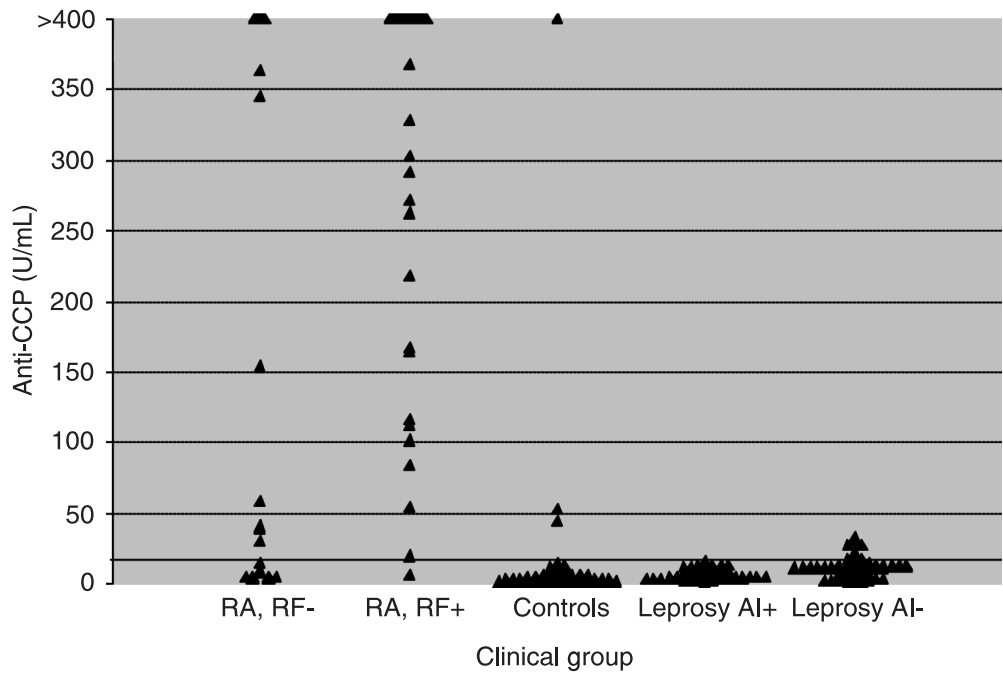

Figure 1. Serum anti-cyclic citrullinated peptide (anti-CCP) antibody concentrations in rheumatoid arthritis (RA) patients with $(\mathrm{RF}+, \mathrm{N}$ $=43$ ) and without (RF-, $N=26$ ) rheumatoid factor, leprosy patients with $(\mathrm{Al}+, \mathrm{N}=76)$ and without ( $\mathrm{Al}-, \mathrm{N}=82$ ) articular involvement manifestations and healthy controls $(\mathrm{N}=89)$.
Articular involvement is the third major clinical complaint in leprosy patients, justifying the necessity for a differential diagnosis between leprosy and RA. The great variability of the frequency of articular involvement reported in the literature $(8,9)$ is probably due to differences in the number of patients studied and in the patient selection criteria.

Leprosy patients can present symmetrical polyarthritis of small joints of hands and feet, mimicking RA, and making the diagnosis of leprosy difficult, particularly when this is the first disease manifestation $(7,29)$.

The difference regarding gender distribution between leprosy and RA was mainly due to the female predominance in RA while leprosy is more frequent in males. Although the usual RA female:male ratio is $3: 1$, in our study this ratio was higher because we included a group of RA female patients evaluated in another study.

There is only one study in the literature addressing the frequency of anti-CCP antibodies in leprosy. The authors studied 64 patients and found only 2 positive cases, both without articular symptoms. However, the number of patients with leprosy-related arthritis was not reported in this study (25). In agreement with the former study, we also found a low frequency of anti-CCP antibodies among 158 leprosy patients, without association with articular involvement.

The frequency of IgM RF among leprosy patients was also similar to that observed among healthy controls, and in agreement with several studies $(11,30,31)$ that reported $\mathrm{RF}$ frequencies ranging from 0.5 to $13.8 \%$ among leprosy patients. However, other studies have reported high frequencies of RF in leprosy, varying from 35 up to $60 \%$ $(5,10,12,32)$. This discrepancy could be explained partially by a number of factors, including the type of assay utilized, study population, and possible role of different treatment regimens (31). Abe et al. (10) and Petchclai et al. (30) evaluated the frequency of RF in leprosy patients using the latex and Waaler Rose tests, and they found higher RF positivity with the Waaler Rose than with the latex test. In contrast, these same authors found that the latex test was more sensitive in RA patients than the other test. In agreement with the results of Atkin et al. (5), we did not find an association between RF and articular involvement. In contrast, Dhople (33) reported a high frequency of RF in leprosy patients with arthritis and suggested that RF could play a role in the pathogenesis of arthritis in acute leprous reaction. However, the group of leprosy patients in that study was very small.

The specificity of anti-CCP antibodies for RA has been established in several studies including other autoimmune and infectious diseases $(16,18-23)$. This is the first study designed to evaluate anti-CCP antibodies in a large number of leprosy patients either with $(\mathrm{N}=76)$ or without $(\mathrm{N}=$ 82) articular involvement. Another study (25), a brief communication, addressed the detection of anti-CCP antibodies in 64 leprosy patients selected on the basis of the stable polar forms of the disease. Although Elkayam et al. (24) reported a high frequency (32\%) of anti-CCP antibodies in patients with active lung tuberculosis, an infectious disease caused by Mycobacterium tuberculosis, it was not clear if this reactivity was directed against citrullinated or non-citrullinated epitopes present in the substrate of the test. In leprosy patients, another mycobacterial infectious disease, we found a low frequency of anti-CCP, comparable to the healthy control group.

In contrast to the high prevalence of RF $(62 \%)$ in 
tuberculosis obtained by Elkayam et al. (24) with ELISA, Rapoport et al. (31) found less than $2 \%$ RF positivity in tuberculosis and less than $0.5 \%$ in leprosy using the latex test.

It is curious that in the present study one healthy woman with no symptoms and no family history of autoimmune disease presented high titers of IgM RF and antiCCP antibodies. One possibility is that in the future this woman will develop RA, in accordance with previous studies that found auto-antibodies in RA patient sera many years before disease manifestation $(15,28)$.

In addition to confirming the good positive predictive values of the anti-CCP assay and RF latex test for RA, the present study shows that both assays can be useful in distinguishing patients with leprosy-induced arthritis from patients with RA.

\section{References}

1. Britton WJ, Lockwood DN. Leprosy. Lancet 2004; 363: 1209-1219.

2. WHO. Leprosy global situation. Wkly Epidemiol Rec 2006; 77: 1-8.

3. Ridley DS, Jopling WH. Classification of leprosy according to immunity. A five-group system. Int J Lepr Other Mycobact Dis 1966; 34: 255-273.

4. Jopling WH. Reactions in leprosy. Lepr Rev 1970; 41: 6263.

5. Atkin SL, el-Ghobarey A, Kamel M, Owen JP, Dick WC. Clinical and laboratory studies of arthritis in leprosy. BMJ 1989; 298: 1423-1425.

6. Cossermelli-Messina W, Festa NC, Cossermelli W. Articular inflammatory manifestations in patients with different forms of leprosy. J Rheumatol 1998; 25: 111-119.

7. Haroon N, Agarwal V, Aggarwal A, Kumari N, Krishnani N, Misra R. Arthritis as presenting manifestation of pure neuritic leprosy - a rheumatologist's dilemma. Rheumatology 2007; 46: 653-656.

8. Modi TH, Lele RD. Acute joint manifestations in leprosyl. $J$ Assoc Physicians India 1969; 17: 247-254.

9. Chavez-Legaspi M, Gomez-Vazquez A, Garcia-De La Torre I. Study of rheumatic manifestations and serologic abnormalities in patients with lepromatous leprosy. $J$ Rheumatol 1985; 12: 738-741.

10. Abe M, Chinone S, Hirako T. Rheumatoid-factor-like substance and antistreptolysin $\mathrm{O}$ antibody in leprosy serum. Significance in erythema nodosum leprosum. Int $\mathrm{J}$ Lepr Other Mycobact Dis 1967; 35: 336-344.

11. Miller RA, Wener MH, Harnisch JP, Gilliland BC. The limited spectrum of antinuclear antibodies in leprosy. $J$ Rheumatol 1987; 14: 108-110.

12. Dacas P, Picanso M, Mouchaileh G, Percegona L, Schultz MT, Silva MGB, et al. Autoantibodies and rheumatic manifestations in pacients with Hansen's disease. An Bras Dermatol 2000; 75: 553-561.

13. Dorner T, Egerer K, Feist E, Burmester GR. Rheumatoid factor revisited. Curr Opin Rheumatol 2004; 16: 246-253.

14. van Venrooij WJ, Hazes JM, Visser H. Anticitrullinated protein/peptide antibody and its role in the diagnosis and prognosis of early rheumatoid arthritis. Neth $J$ Med 2002; 60: 383-388.

15. Nell VP, Machold KP, Stamm TA, Eberl G, Heinzl H, Uffmann $\mathrm{M}$, et al. Autoantibody profiling as early diagnostic and prognostic tool for rheumatoid arthritis. Ann Rheum Dis 2005; 64: 1731-1736.
16. Sauerland $U$, Becker $H$, Seidel $M$, Schotte $H$, Willeke $P$, Schorat A, et al. Clinical utility of the anti-CCP assay: experiences with 700 patients. Ann N Y Acad Sci 2005; 1050: 314-318.

17. Nishimura K, Sugiyama D, Kogata Y, Tsuji G, Nakazawa T, Kawano S, et al. Meta-analysis: diagnostic accuracy of anticyclic citrullinated peptide antibody and rheumatoid factor for rheumatoid arthritis. Ann Intern Med 2007; 146: 797808.

18. Mediwake R, Isenberg DA, Schellekens GA, van Venrooij WJ. Use of anti-citrullinated peptide and anti-RA33 antibodies in distinguishing erosive arthritis in patients with systemic lupus erythematosus and rheumatoid arthritis. Ann Rheum Dis 2001; 60: 67-68.

19. Hoffman IE, Peene I, Cebecauer L, Isenberg D, Huizinga TW, Union A, et al. Presence of rheumatoid factor and antibodies to citrullinated peptides in systemic lupus erythematosus. Ann Rheum Dis 2005; 64: 330-332.

20. Lopez-Hoyos M, Ayerbe I, Martinez-Taboada VM, Bartolome MJ, Blanco R, Lopez-Escribano $\mathrm{H}$, et al. Clinical utility of antibodies to double-stranded DNA by a new immunofluorescence test. Lupus 2004; 13: 144-147.

21. Fusconi M, Vannini A, Dall'Aglio AC, Pappas G, Cassani F, Ballardini G, et al. Anti-cyclic citrullinated peptide antibodies in type 1 autoimmune hepatitis. Aliment Pharmacol Ther 2005; 22: 951-955.

22. Bombardieri $M$, Alessandri $C$, Labbadia G, lannuccelli $C$, Carlucci F, Riccieri V, et al. Role of anti-cyclic citrullinated peptide antibodies in discriminating patients with rheumatoid arthritis from patients with chronic hepatitis $\mathrm{C}$ infectionassociated polyarticular involvement. Arthritis Res Ther 2004; 6: R137-R141.

23. Wener MH, Hutchinson K, Morishima C, Gretch DR. Absence of antibodies to cyclic citrullinated peptide in sera of patients with hepatitis $\mathrm{C}$ virus infection and cryoglobulinemia. Arthritis Rheum 2004; 50: 2305-2308.

24. Elkayam O, Segal R, Lidgi M, Caspi D. Positive anti-cyclic citrullinated proteins and rheumatoid factor during active lung tuberculosis. Ann Rheum Dis 2006; 65: 1110-1112.

25. Guedes-Barbosa LS, Mangueira C, Scheinberg M. Anticitrulline peptide antibodies (CCP3) in leprosy sera: a negative association. Clin Rheumatol 2008; 27: 515-516.

26. Arnett FC, Edworthy SM, Bloch DA, McShane DJ, Fries JF, Cooper NS, et al. The American Rheumatism Association 1987 revised criteria for the classification of rheumatoid arthritis. Arthritis Rheum 1988; 31: 315-324. 
27. Dubucquoi S, Solau-Gervais E, Lefranc D, Marguerie L, Sibilia J, Goetz J, et al. Evaluation of anti-citrullinated filaggrin antibodies as hallmarks for the diagnosis of rheumatic diseases. Ann Rheum Dis 2004; 63: 415-419.

28. Avouac J, Gossec L, Dougados M. Diagnostic and predictive value of anti-cyclic citrullinated protein antibodies in rheumatoid arthritis: a systematic literature review. Ann Rheum Dis 2006; 65: 845-851.

29. Pernambuco JC, Cossermelli-Messina W. Rheumatic manifestations of leprosy: clinical aspects. J Rheumatol 1993; 20: $897-899$
30. Petchclai B, Chuthanondh R, Rungruong S, Ramasoota T. Autoantibodies in leprosy among Thai patients. Lancet 1973; 1: 1481-1482.

31. Rapoport BL, Morrison RC, Sher R, Dos Santos L. A study of autoantibodies in chronic mycobacterial infections. Int $J$ Lepr Other Mycobact Dis 1990; 58: 518-525.

32. Cathcart ES, Williams RC Jr, Ross H, Calkins E. The relationship of the latex fixation test to the clinical and serologic manifestations of leprosy. Am J Med 1961; 31: 758-765.

33. Dhople AM. Possible autoimmune phenomenon in leprosy. Jpn J Exp Med 1972; 42: 125-129. 